\title{
PENINGKATAN PENGETAHUAN, KETERAMPILAN DAN PENDAPATAN MASYARAKAT BERBASIS KONSERVASI DAN EKOWISATA DI LERENG PEGUNUNGAN GAWALISE DESA UWEMANJE KECAMATAN KINOVARO KABUPATEN SIGI SULAWESI TENGAH
}

\author{
Yusran $^{1^{*}}$, Erniwati $^{1}$, Sustri $^{1}$, Risnawati $^{2}$ \\ ${ }^{1}$ Fakultas Kehutanan, Universitas Tadulako, Palu, Indonesia \\ ${ }^{2}$ Fakultas Ekonomi, Universitas Tadulako, Palu, Indonesia \\ *Penulis Korespondensi: yusran_ysrn@yahoo.ca
}

\begin{abstract}
Abstrak
Desa Uwemanje merupakan desa berpotensi di lereng pegunungan Gawalise yang memiliki topografi berbukit dimana sebagian besar lahan memiliki tingkat kemiringan lereng lebih dari $40 \%$, sehingga praktek pertanian di desa ini sangat rawan terhadap erosi dan degradasi lahan lainnya. Komoditas utama terpenting di desa ini adalah Hasil Hutan Bukan Kayu seperti tegakan pinus, kemiri dan bambu yang merupakan hasil reboisasi pada lahan kritis yang berada di desa ini. Program pengembangan desa mitra tahun kedua ini adalah pembinaan tiga mitra yaitu kelompok tani, ibu-ibu PKK dan Pemuda Sadar Wisata dalam pengembangan dan promosi ekowisata. Permasalahan yang diatasi melalui program ini yaitu rendahnya pengetahuan dan keterampilan masyarakat sasaran serta tidak tersedianya bibit tanaman yang dibutuhkan oleh masyarakat setempat. Metode-metode pendekatan yang ditawarkan dalam bentuk pendidikan dan pelatihan bagi mitra melalui penyuluhan dan pendampingan/pelatihan yang berupa bimbingan teknis dan pembinaan kelompok tani dalam budidaya dan pembibitan tanaman, pemanfaatan limbah buah pinus sebagai souvenir, pembuatan kuliner berbahan baku lokal, pembuatan blog desa ekowisata serta pengadaan sarana penunjang ekowisata. Hasil dari PPDM yaitu tersedianya \pm 3000 bibit tanaman, lokasi persemaian bagi kelompok tani, produk kuliner berbahan baku lokal serta souvenir yang berbahan baku limbah pinus, Blog desa serta obyek ekowisata yang akan terus dikembangkan dimasa depan.
\end{abstract}

Kata Kunci: Hasil Hutan Bukan Kayu, Ekowisata, Konservasi, Souvenir, Pendapatan.

\begin{abstract}
The village of Uwemanje is a village potentially on the slopes of the Gawalise mountain range which has a hilly topography where most of the land has a slope of more than 40\%, so agricultural practices in this village are very prone to erosion and other land degradation. The most important main commodity in this village is Non-Timber Forest Products such as stands of pine, candlenut and bamboo which are the result of reforestation on critical land in this village. The second year of the partner village development program is fostering three partners namely farmer group, PKK group and Pemuda Sadar Wisata group in the development and promotion of ecotourism. The problem that was overcome in the second year was the lack of knowledge and skills of the target community and the unavailability of plant seedlings needed by the local community. Approach methods offered in the form of education and training for partners through counseling and training in the form of technical guidance and coaching of farmer groups in crop cultivation and nurseries, utilization of pine waste as souvenirs, making local-based culinary, ecotourism village blogging and procurement of ecotourism supporting facilities. The results of PPDM program are the availability of \pm 3000 plant seedlings, nursery locations for farmer groups, local-based culinary products as well as souvenirs made from pine waste and, Blog/Website of ecotourism villages and ecotourism objects to be developed.
\end{abstract}

Keywords: Non-Timber Forest Products, Ecotourism, Conservation, Souvenir, Income. 


\section{PENDAHULUAN}

\subsection{Analisis Situasi}

Desa Uwemanje merupakan salah satu desa yang berada di Kecamatan Kinovaro Kabupaten Sigi Propinsi Sulawesi Tengah terletak di lereng Pegunungan Gawalise. Kawasan Hutan Lindung di desa ini dari dari tahun ke tahun selalu mendapat gangguan misalnya; illegal logging, kebakaran hutan dan praktek budidaya tanaman yang masih konvensional yang tidak memperhatikan kaidah konservasi.

Desa Uwemanje memiliki potensi hasil hutan bukan kayu (HHBK) yang sangat besar. Komoditas HHBK utama dan penting di desa ini adalah tegakan pinus (Pinus merkusii), kemiri dan bambu. Saat ini merupakan kawasan konservasi tanah dan penyimpan air (water reservoir) bagi sumber mata air bagi desa uwemanje dan desa sekitarnya. Selain tegakan Pinus, desa Uwemanje juga merupakan kantong produksi kemiri dengan luas \pm $60 \mathrm{Ha}$. Sebagian besar petani di desa ini mengusahakan tanaman Kemiri (Aleurites moluccana Wild.) karena produk berupa biji dan kayunya yang memiliki nilai jual yang sangat tinggi dipasaran sehingga sangat berperan penting dalam peningkatan kesejahteraan masyarakat di desa ini.

Dalam prakteknya di lapangan sistem pertanaman tersebut dilakukan secara monokultur, padahal model pertanaman Agroforestri dapat dipraktekan karena lebih menguntungkan dimana lahan diantara barisan tanaman pinus dan kemiri dapat ditanami tanaman pertanian misalnya jagung, kacang-kacangan dan umbianumbian. Selain itu, para petani masih menggunakan teknik budidaya konvensional yang tidak mengacu kepada kaidah/teknik budidaya dan konservasi tanah dan air yang benar, misalnya tidak adanya peremajaan tanaman, penanaman bibit tanaman yang berkualitas rendah karena masih mengandalkan anakan alam yang diperoleh di sekitar tegakan kemiri atau hutan alam, belum adanya teknologi pemupukan baik pupuk organik maupun anorganik, tidak adanya usaha pemberantasan hama dan penyakit tanaman dan penanaman pada sebagian besar areal yang memiliki topografi berbukitbukit tanpa pembuatan sengkedan atau terrassering. Selain kedua jenis tanaman hutan tersebut, Bambu merupakan hasil hutan bukan kayu yang tersedia melimpah juga di desa ini.

Hutan pinus, kemiri dan bambu sangat berpotensi sebagai agrowisata, dan didesa Uwemanje juga memiliki potensi ekowisata lain yaitu kolam permandian alam yang terdapat di bagian lembah lereng pegunungan Gawalise, yang jaraknya hanya 0,5 Km dari pemukiman penduduk. Di sekeliling permandian alam ini masih dikelilingi oleh hutan alam yang didalamnya terdapat berbagai jenis flora dan fauna endemic Sulawesi, misalnya Kayu Hitam/Eboni (Disopyros celebica), Tarsius, Musang Sulawesi, Rusa, dan sebagainya. Potensi ekowisata ini belum banyak diketahui oleh masyarakat luar sehingga perlu dipromosikan.
Menurut data Badan Pusat Statistik Kabupaten Sigi (2015), bahwa Kabupaten Sigi khususnya Kecamatan Kinovaro berpenduduk \pm 6.256 Jiwa sebagian besar merupakan daerah dimana masyarakatnya berprofesi sebagai petani, khusus untuk Desa Uwemanje mempunyai jumlah 386 KK. Daerah ini merupakan wilayah dengan kearifan lokal yang sangat menjunjung tinggi akan nilai-nilai usaha konservasi sumberdaya alam khususnya pemanfaatan hutan dan lahan. Salah satu wujud nyata kearifan lokal dari usaha konservasi hutan dan lahan yang masih terlihat adalah dengan membagi hutan ke dalam sistem pemanfaatan yaitu hutan primer, sekunder dan tegalan. Mata pencaharian utama masyarakat adalah Petani lahan kering khususnya kemiri dan pinus berbasis agroforestri. Jarak dari Kota Palu ke desa Uwemanje $\pm 25 \mathrm{~km}$ sedangkan jarak dari ibukota Kabupaten sekitar 40 km, yang dapat diakses dengan kendaraan angkutan umum.

Dari aspek sosial, budaya dan ekonomi, penduduk desa Uwemanje adalah merupakan penduduk asli dari Suku Kaili rumpun Da'a yang merupakan suku asli di propinsi Sulawesi Tengah. Mereka mendiami daerah pegunungan Gawalise di sisi barat lembah Palu dan di daerah pegunungan Verbeek di sisi timur Lembah Palu. Masyarakat desa Uwemanje mayoritas bekerja sebagai petani, dengan kondisi topografi desa yang berbukitbukit serta berbatasan langsung dengan kawasan konservasi penting hutan lindung, desa ini sangat berpotensi untuk dijadikan sebagai Desa Sentra Produksi Hasil Hutan Bukan Kayu yang berbasis agroforestri, konservasi dan ekowisata. Olehnya itu, program Pengabdian pada masyakarat ini diharapkan dapat memotivasi dan meningkatkan pengetahuan dan keterampilan masyarakat tani di desa ini dalam hal teknik budidaya tanaman yang benar, pengolahan hasil dan limbah tanaman pinus menjadi souvenir serta pembuatan terassering/sengkedan pada lahan bertopografi miring, yang pada akhirnya dapat meningkatkan perekonomian desa.

\subsection{Urgensi Permasalahan Prioritas}

Pengetahuan dan kearifan lokal masyarakat Desa Uwemanje Kecamatan Kinovaro Kabupaten Sigi yang berkaitan dengan praktek-praktek konservasi dan teknik budidaya pinus (tusam), kemiri dan bambu perlu didukung oleh pengetahuan ilmiah yang relevan sehingga memperkuat nilai-nilai kearifan lokal. Masyarakat Desa Uwemanje perlu memperoleh pengetahuan konsep-konsep dan teori yang bersifat ilmiah yang menerangkan dan melatarbelakangi praktek-praktek budidaya pinus, kemiri dan bambu berbasis agroforestri, konservasi dan ekowisata. Dengan pengetahuan ilmiah ini, masyarakat Desa Uwemanje diharapkan lebih memperkuat praktek dan pengetahuan lokalnya dalam mengelola lahan yang mereka miliki guna peningkatan produktivitas lahan secara berkelanjutan dan peningkatan pendapatan serta kesejahteraan mereka.

Masyarakat di Desa Uwemanje Kecamatan Kinovaro selama ini senantiasa menghadapi berbagai hambatan 
dan tantangan dalam meningkatkan Produktivitas lahan usaha tani mereka. Hambatan tersebut adalah terkait dengan sistem produksi usaha tani seperti tingkat kesuburan tanah yang rendah, aplikasi teknologi pengolahan lahan dan tanaman pinus, kemiri dan bambu yang masih konvensional serta sistem tindakan konservasi tanah pada lahan miring yang masih belum menguasai teknologi.

Berdasarkan hal tersebut, maka perlu dilakukan pemberdayaan masyarakat agar kegiatan yang mereka lakukan dapat berlangsung secara berkelanjutan, selain itu diperlukan inovasi teknologi secara ilmiah yang bisa mengatasi berbagai hambatan yang dihadapi oleh kelompok tani tersebut, supaya lahan yang mereka kembangkan produktivitasnya bisa meningkat dan dapat berlangsung secara berkelanjutan. Program pengabdian yang ditawarkan sesuai untuk mengatasi permasalahan yang dihadapi oleh masyarakat sasaran dan merupakan program yang relevan dan sejalan dengan program pembangunan desa, Kecamatan maupun Kabupaten. Oleh karena itu, tujuan dari program pengabdian ini adalah untuk meningkatkan pengetahuan, keterampilan dan pendapatan masyarakat yang berbasis konservasi dan ekowisata di lereng pegunungan Gawalise Desa Uwemanje, Kecamatan Kinovaro, Kabupaten Sigi, Sulawesi Tengah.

\section{METODE PELAKSANAAN}

Langkah-langka operasional untuk mengatasi permasalahan yang dihadapi oleh kelompok masyarakat sasaran dalam program pengabdian ini adalah:

\subsection{Pelaksanaan}

\section{1) Sosialisasi Program}

Program pengabdian ini merupakan kegiatan-kegiatan dari Program Pengembangan Desa Mitra (PPDM) tahun kedua. Sosialisasi PPDM dikoordinasikan dengan Pemerintah Daerah Kabupaten Sigi dan juga dilaksanakan di balai Desa Uwemanje, dengan tujuan untuk menyampaikan maksud, tujuan dan sasaran kegiatan PPDM serta membuat kesepakatan awal untuk rencana tindaklanjut yang akan diimplementasikan di lapangan. Kegiatan sosialisasi ini dilakukan terhadap kelompok sasaran dan tokoh adat serta masyarakat, aparat pemerintah desa dan kecamatan serta petugas pelaksana dari instansi terkait. Materi sosialisasi disampaikan oleh narasumber yang berasal dari pelaksana program PPDM dari Universitas Tadulako, Ketua Lembaga Penelitian dan Pengabdian Kepada Masyarakat (LPPM) Universitas Tadulako, Perwakilan Dinas Kehutanan dan Perkebunan Kabupaten Sigi dan Dinas Pertanian Kabupaten Sigi.

\subsection{Metode Pendekatan Dalam Penyelesaian Masalah-masalah yang dihadapi oleh kelompok masyarakat sasaran adalah:}

\section{1) Metode Penyuluhan}

Kegiatan penyuluhan ini dilakukan dengan pendekatan partisipatif peserta sebagai sasaran yang dilibatkan dari awal sampai akhir kegiatan dalam program ini. Dalam kegiatan ini melibatkan 25 orang anggota yang ada pada masing-masing Kelompok mitra sasaran. Kegiatan penyuluhan ini meliputi:

- Penyampaian teori-teori yang berkaitan dengan budidaya kemiri (Krisnawati dkk., 2011) dan juga tanaman lainnya.

- Penyampaian teori-teori yang berkaitan dengan budidaya dan pengolahan bambu (Sutiyono, 2012; Yuniarti, 2006).

- Penyampaian teori-teori tentang konservasi tanah dan air pada lahan kering (Erfandi, 2013) dan teknik konservasi tanah dan air secara vegetatif (Subagyono dkk., 2003).

- Pengenalan jenis limbah tanaman pertanian dan pemanfaatannya sebagai bahan baku pembuatan kompos dan kerajinan tangan (Suwastika dkk., 2013).

- Teori-teori strategi pengembangan dan pemberdayaan masyarakat dan Usaha Tani (Rasyid dkk., 2010; Shinta A, 2011).

- Teori-teori dan hasil riset pengembangan ekowisata/agrowisata (Suriadikusumah, 2012).

- Teori-teori strategi pemasaran ekowisata (Widagdyo, 2017).

\section{2) Metode Pelatihan dan Pembinaan}

Kegiatan pelatihan dan pembinaan ini dilakukan dengan cara penerapan langsung di lapangan materi-materi yang telah didapatkan yang terdiri dari teknik budidaya kemiri yang meliputi ; pemilihan benih kemiri maupun benih tanaman MPTS lainnya yang baik dan benar dan layak untuk dibibitkan, teknik pembibitan kemiri serta tanaman MPTS lainnya serta aplikasi teknologi pupuk organic/kompos, pembuatan terassering/sengkedan, pembuatan souvenir dari konus/buah pinus, pembuatan kuliner berbahan baku lokal, pembuatan blog, bahasa Inggris, penggunaan GPS, pembuatan blog desa dan leaflet promosi ekowisata, pendampingan manajemen produksi dan pemasaran dan hal terkait lainnya. Evaluasi terhadap pelaksanaan program pengabdian ini bertujuan untuk melihat sejauh mana penguasaan materi oleh peserta juga untuk melihat respon dan tanggapan peserta terhadap kegiatan program pengabdian ini.

Tahapan-tahapan kegiatan-kegiatan dalam program pengabdian ini meliputi:

a. Kegiatan Penyuluhan

Penyuluhan ini melibatkan sekitar 25 orang untuk masing-masing Mitra. Kegiatan ini dilakukan sebagai langkah awal sebelum program pelatihanpelatihan dilakukan. Dalam penyluhan ini akan diberikan materi-materi sesuai dengan program pelatihan.

b. Kegiatan Pelatihan dan Pembinaan

1. Cara Pembibitan bambu

Pembibitan bambu, stek yang berukuran $30 \mathrm{~cm}$ dengan jumlah buku 2, langsung ditanam dalam 
polibag dan dalam lubang tanam yang berisi mikoriza dan pupuk kompos. Sebelum ditanam, stek bambu direndam dalam larutan Pupuk cair Bambu Ijo selama 1 jam untuk merangsang pertumbuhan akarnya. Stek bambu ini dipelihara selamat empat bulan.

2. Cara Penggunaan Inokulum Mikoriza sebagai campuran media tumbuh pembibitan bambu.

Tanah dicampur dengan pasir yang telah dipilih untuk dijadikan sebagai medium tumbuh dengan perbandingan tertentu. Selanjutnya inokulum mikoriza di campur dengan medium tumbuh yang telah dicampur dengan arang tersebut sebanyak 15 gr per polybag medium tumbuh. Bibit kemiri yang akan disemai diperoleh dari bedeng perkecambahan yang telah dilakukan sebelumnya. Pemeliharaan yang dilakukan yaitu penyiraman dan pengendalian hama dan pathogen penyebab penyakit pada bibit.

3. Pelatihan Pembuatan souvenir dari konus/buah pinus a)Alat dan bahan : Solatip berwarna atau bercorak (washi tape), Buah Pinus, Lem Tembak, Gunting, Cutter, Kain flanel berwarna merah dan kuning,Mata boneka,Stik es krim. b) Cara kerja; Beberapa stik es krim yang telah disiapkan dipotong menjadi 2 bagian dengan menggunakan cutter. Stik tersebut diukur sama panjang dengan sisinya. Kemudian stik es krimnya bisa dipotong. Lalu didiamkan selama beberapa saat. Kemudian potong bagian lebih dari solatip itu. Caranya potong sisa solatip dengan memotong solatipnya mengikuti bentuk stik es krim yang menempel. Agar lebih indah. Setelah dibuat dan disesuaikan dengan jumlah, kemudian hiasan dibuat untuk buah pinusnya. Kain flanel yang telah disiapkan di potong bentuk segi tiga untuk warna kuning dan bentuk lidah untuk flanel berwarna merah. Setelah dibuat, ambil buah pinusnya diambil dan diposisikan buah pinus pada hadapan kita.

4. Bimbingan teknis/aplikasi demplot pembuatan Teras Individu dan Kontur dengan bingkai A dan teknik pembuatan saluran pengendali air. Teras kontur (Contour terrace) adalah suatu teras berbentuk guludan yang dibuat melintang lereng mengikuti garis kontur. Teras kontur cocok diaplikasikan pada lahan dengen kemiringan lerenag 10\% 50\% (Rukmana, 1995). Tahapan pembuatan teras kontur dengan menggunakan alat bingkai A dengan jalan menentukan letak teras permulaan, menentukan garis kontur, menentukan garis kontur berikutnya, menentukan jarak barisan kontur serta pembuatan teras.

5. Pembuatan leaflet potensi ekowisata di Desa Uwemanje untuk disebarkan ke pengunjung. Selain leaflet, juga dibuat papan-papan penunjuk yang berisi informasi tentang obyek ekowisata di desa Uwemanje. Papan penunjuk ditempatkan ditempattempat strategies di Desa ini.

6. Pelatihan penggunaan GPS dan Bahasa Inggris bagi kelompok pemuda sadar wisata.

7. Promosi potensi ekowisata desa Uwemanje di Harian/Surat Kabar Lokal maupun Radio.
8. Pembuatan Blog Desa Sentra Produksi Hasil Hutan Bukan Kayu Berbasis Agroforestri, Konservasi dan Ekowisata.

9. Pendampingan dalam perbaikan manajemen produksi dan pemasaran produk-produk yang dihasilkan dari program PPDM diatas.

\section{HASIL}

Kegiatan-kegiatan yang telah dilaksanakan melalui program Program Pengembangan Desa Mitra (PPDM) tahun kedua ini adalah sebagai berikut:

1. Koordinasi Dan sosialisasi Program Pengembangan Desa Mitra (PPDM) Tahun 2018 dengan Bupati Sigi serta Dinas terkiat yaitu Dinas Lingkungan Hidup dan Pariwisata Kabupaten Sigi, Kepala Desa, Perangkat Desa Uwemanje, Kecamatan Kinovaro, Kabupaten Sigi serta anggota kelompok mitra.

2. Penyuluhan-penyuluhan berkaitan dengan Pembibitan tanaman MPTS, Kebakaran hutan dan dampaknya, pembuatan terassering, pembuatan souvenir dari limbah tanaman Pinus (Pinus merkusii) pembuatan kuliner berbahan baku lokal dan Pembuatan Blog dan Pengembangan Desa Ekowisata dan strategi pengembangan dan pemasaran ekowisata.

3. Pelatihan-pelatihan yang terdiri atas Pembuatan Persemaian tanaman MPTS, Terassering, Kuliner Berbahan Baku Lokal, dan Blog Desa Ekowisata.
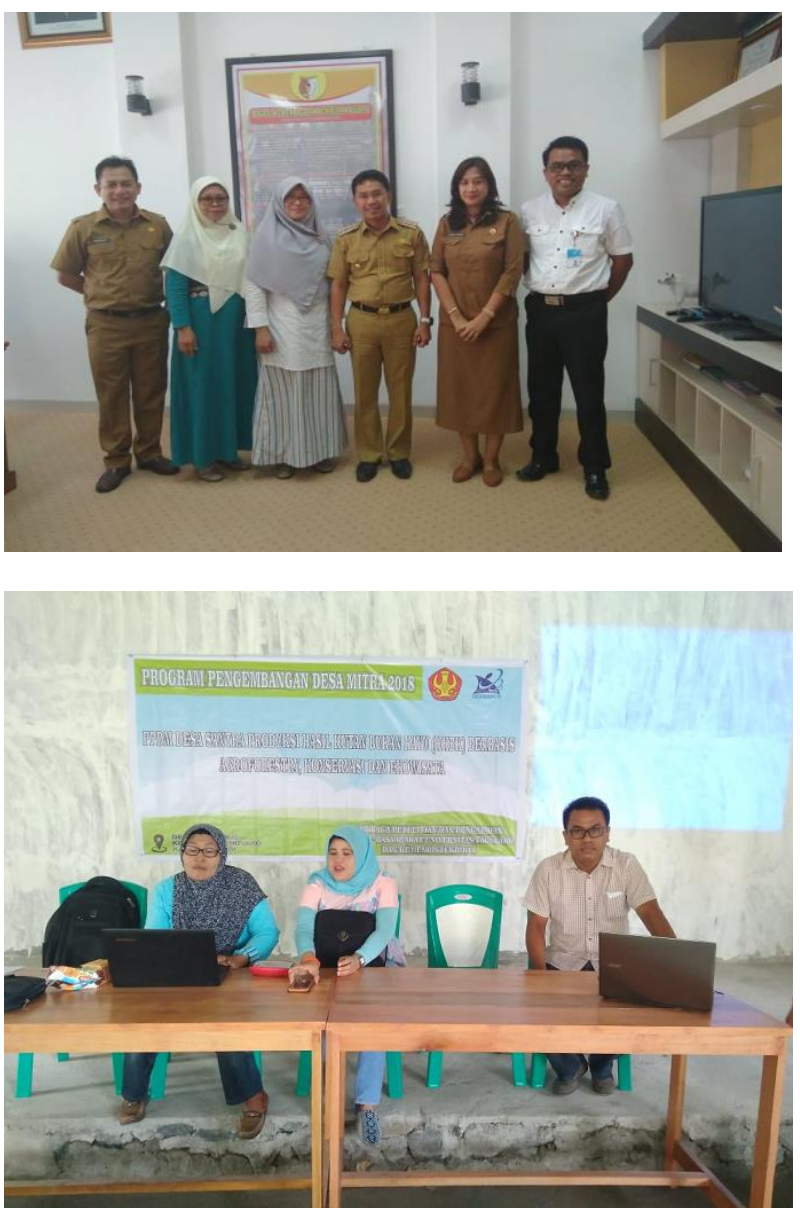


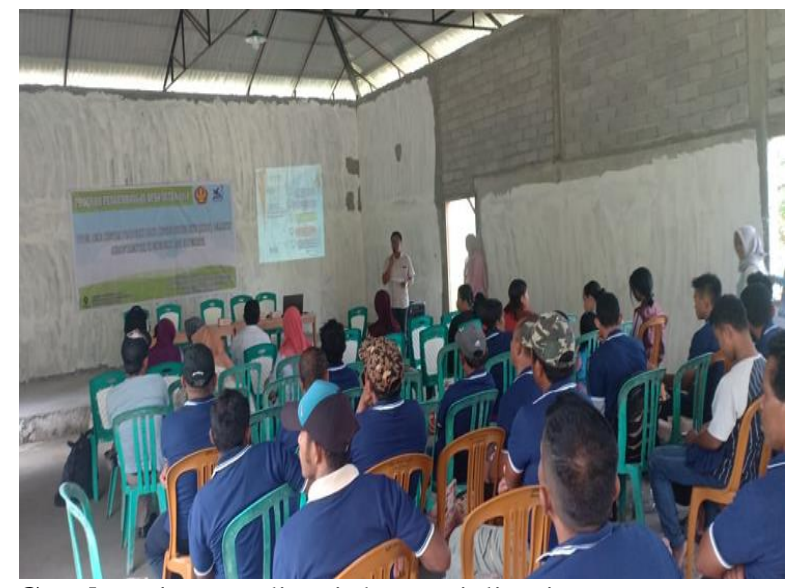

Gambar 1. Koordinasi dan sosialisasi program PPDM dengan Bupati Sigi serta Dinas Lingkungan Hidup dan Dinas Pariwisata Sigi, Kepala desa dan perangkat desa Uwemanje serta ketua-ketua kelompok tani, Ibu PKK dan Pemuda.

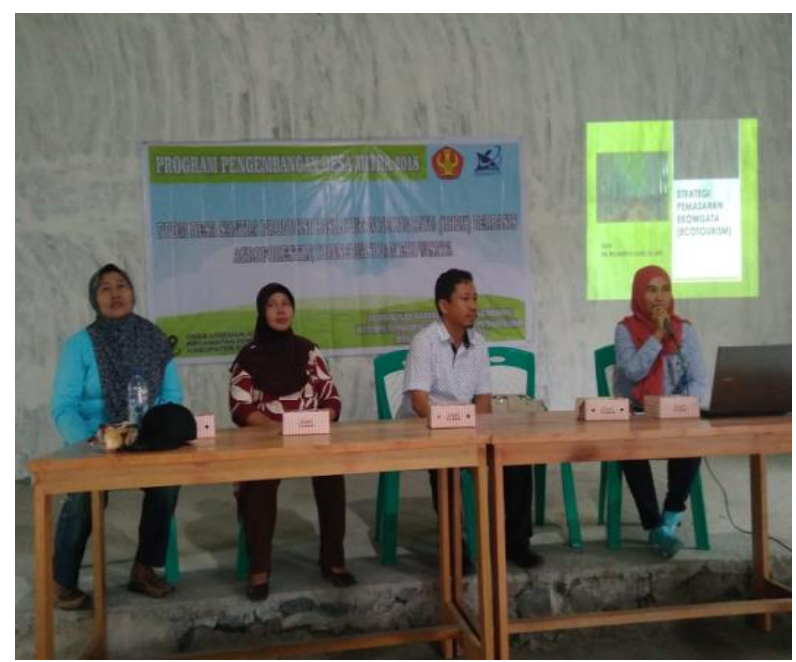

Gambar 2. Penyuluhan tentang Kebakaran Hutan dan strategi pemasaran ekowisata.

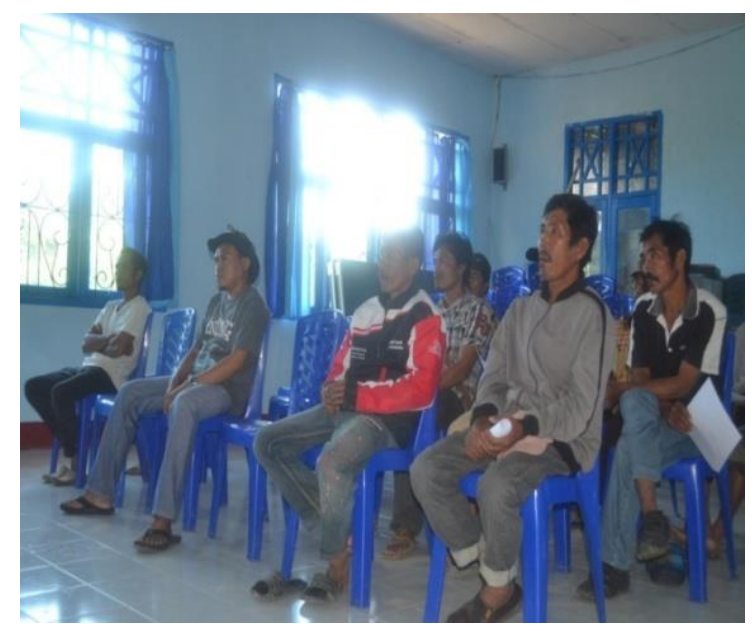

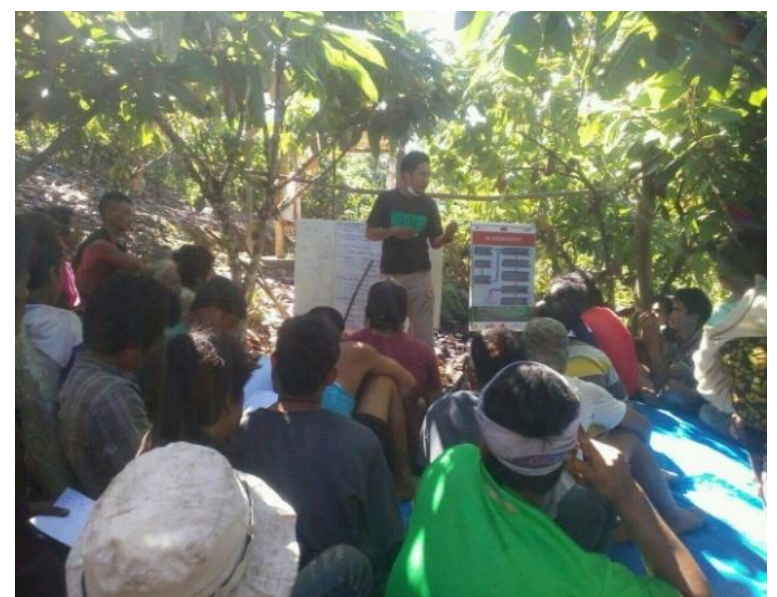

Gambar 3. Penyuluhan Budidaya tanaman MPTS dan Pembuatan Terassering.
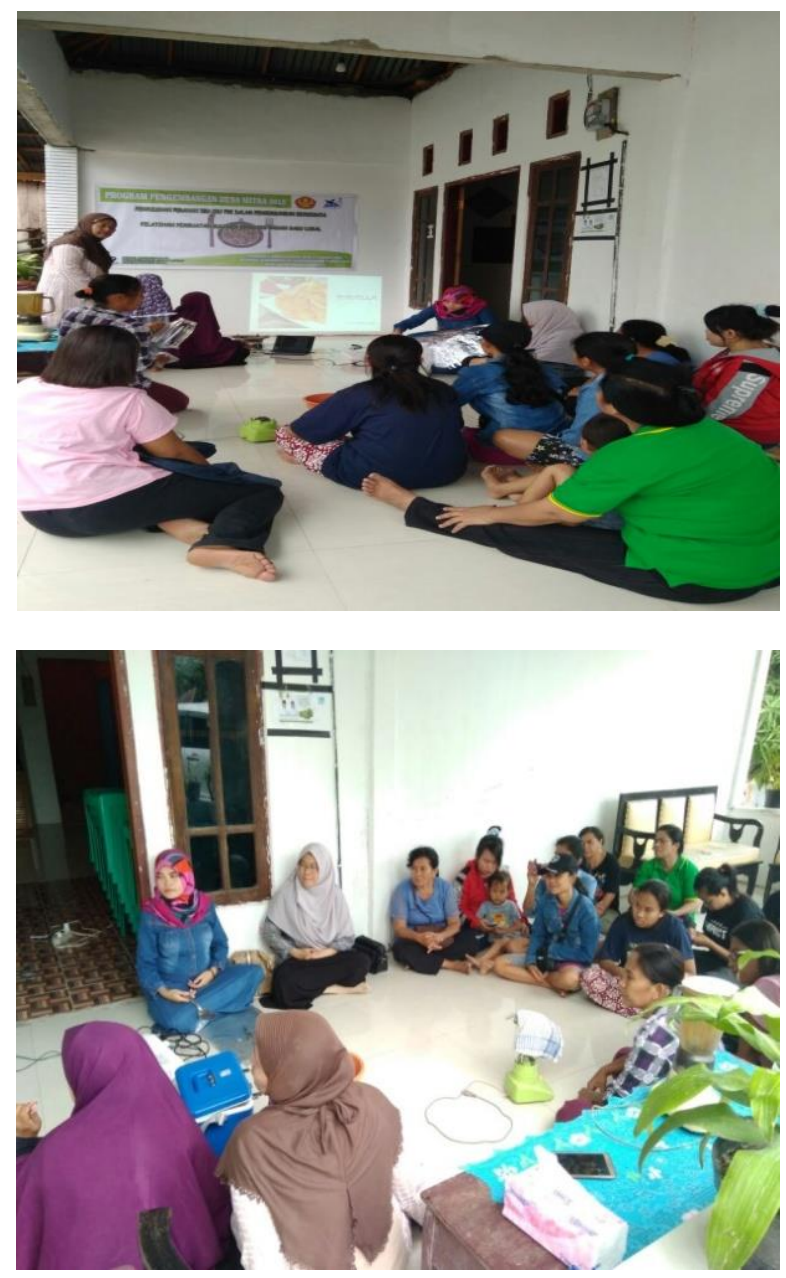

Gambar 4. Penyuluhan pembuatan kuliner berbahan baku lokal bagi ibu-ibu kelompok tani/PKK. 

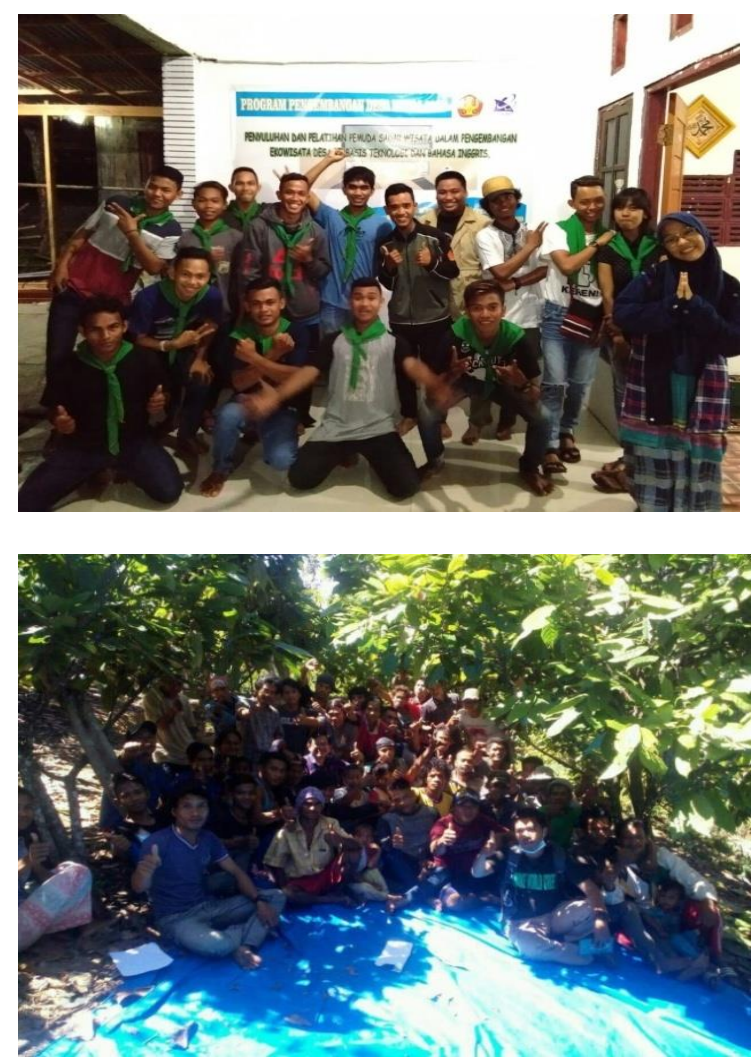

Gambar 5. Penyuluhan tentang peranan pemuda dalam pengembangan ekowisata desa dan cara pembuatan blog desa ekowisata bagi pemuda desa.

a. Pelatihan Budidaya tanaman MPTS/Tanaman konservasi.
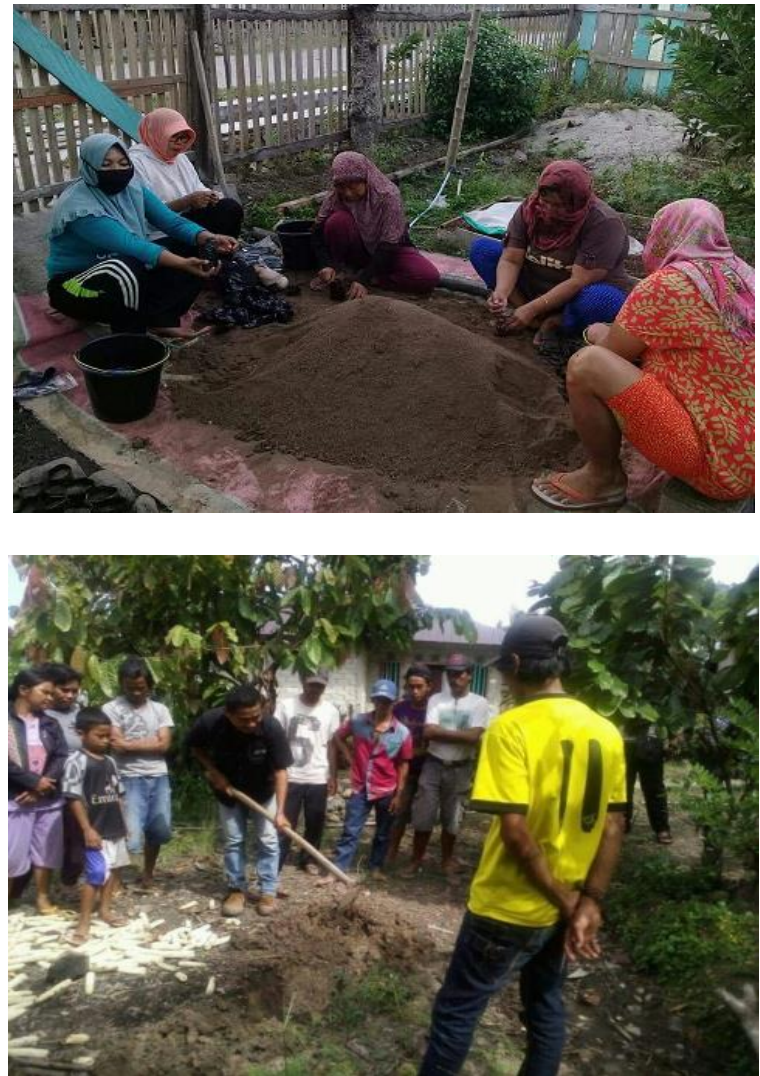
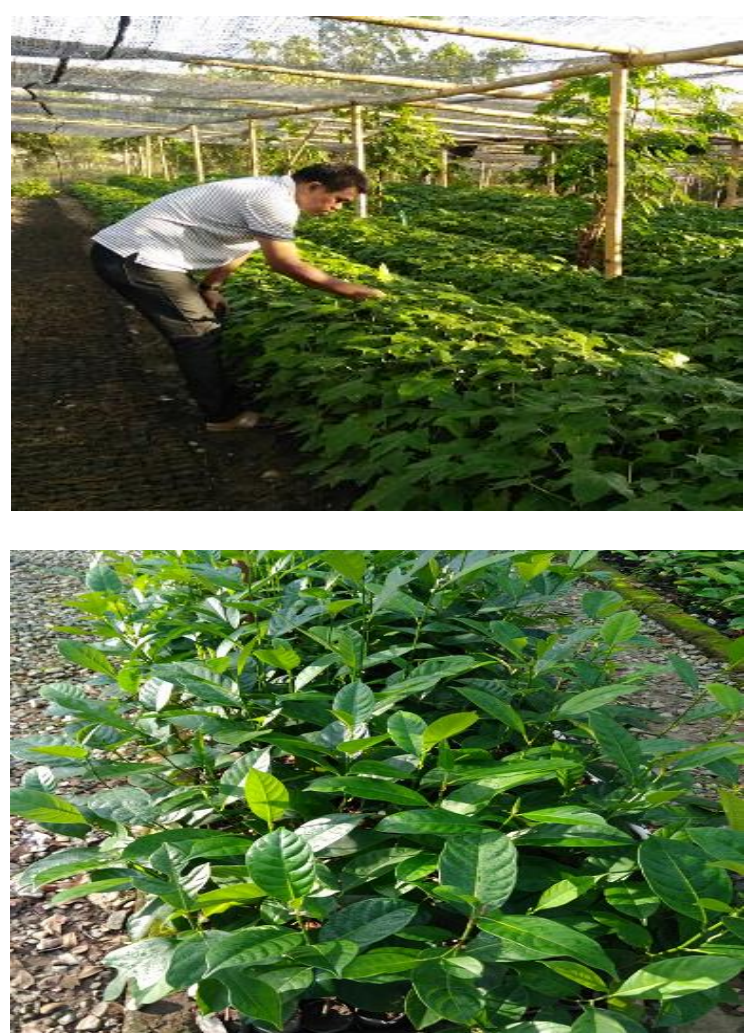

Gambar 6. Pelatihan Pembuatan Pembibitan kemir dan tanaman MPTS lainnya.

b. Pelatihan Pembuatan Terassering di lahan miring.
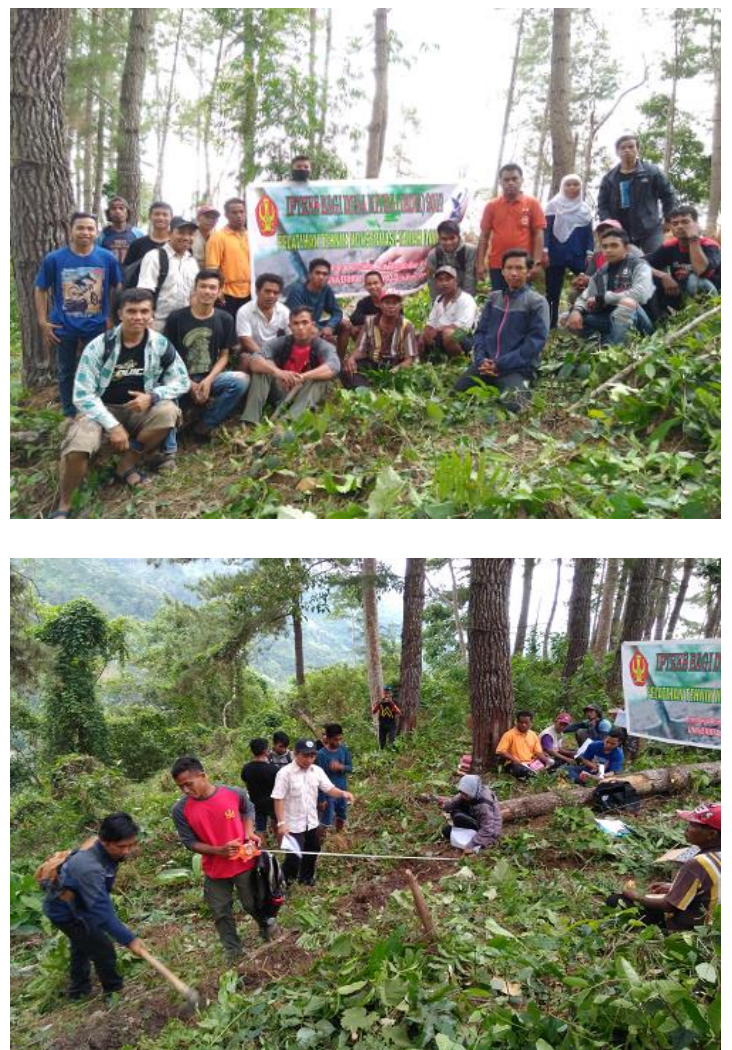

Gambar 7. Pelatihan Pembuatan Terasssering 
c. Pelatihan Pembuatan Souvenir Berbahan Baku Limbah Pinus.
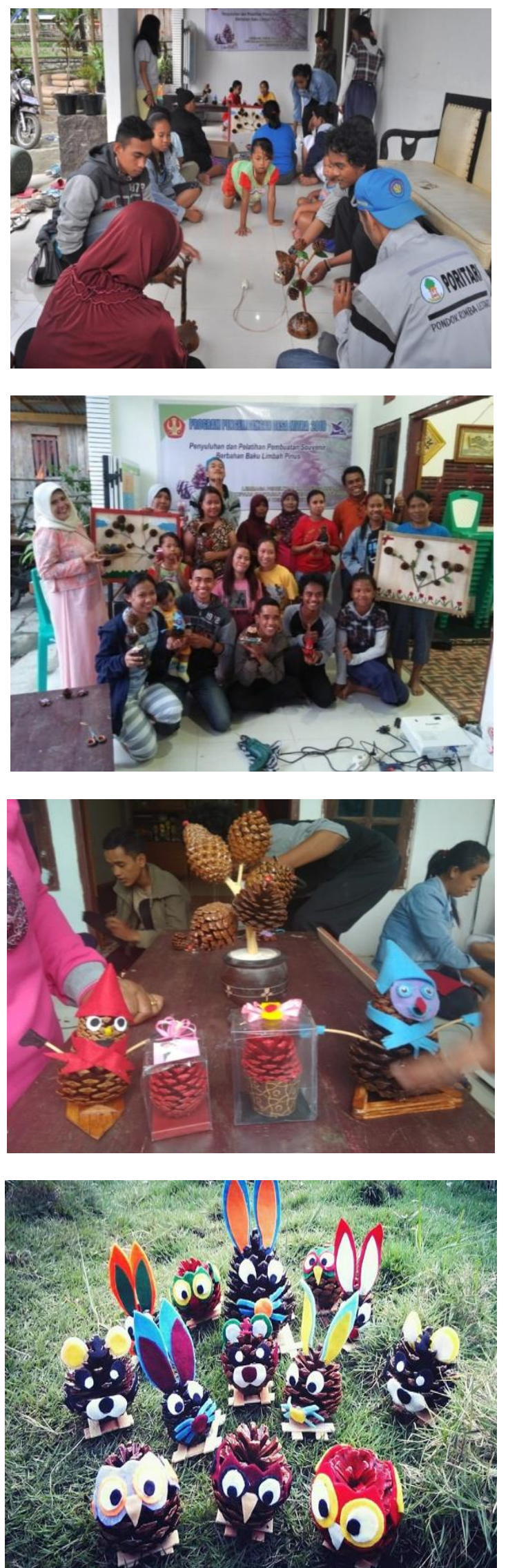

Gambar 8. Pelatihan Pembuatan Souvenir berbahan baku limbah tanaman pinus. d. Pelatihan Pembuatan Kuliner Berbahan Baku lokal guna mendukung promosi ekowisata desa
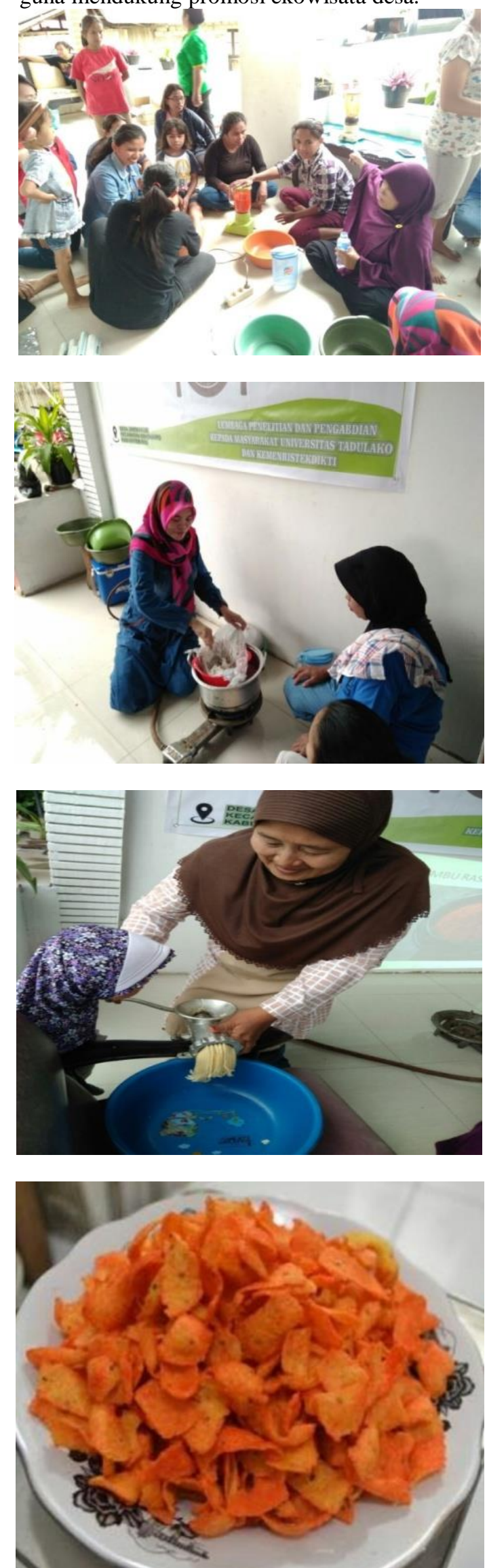

Gambar 9. Pelatihan Pembuatan Kuliner Berbahan Baku Lokal setempat. 
e. Pelatihan Pembuatan Blog Desa Ekowisata bagi Pemuda Sadar Wisata.
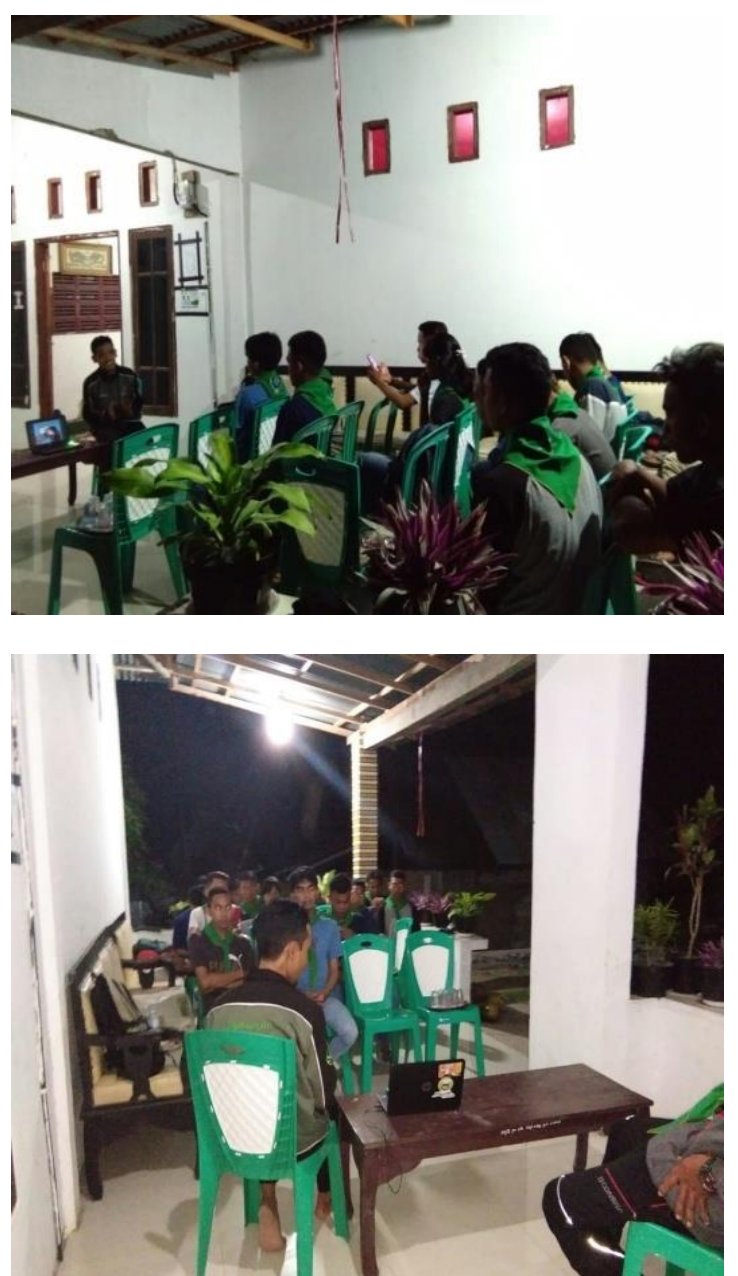

Gambar 10. Pelatihan Pembuata Blog Desa Ekowisata bagi pemuda.

f. Penanaman Tanaman Di Lokasi Ekowisata.

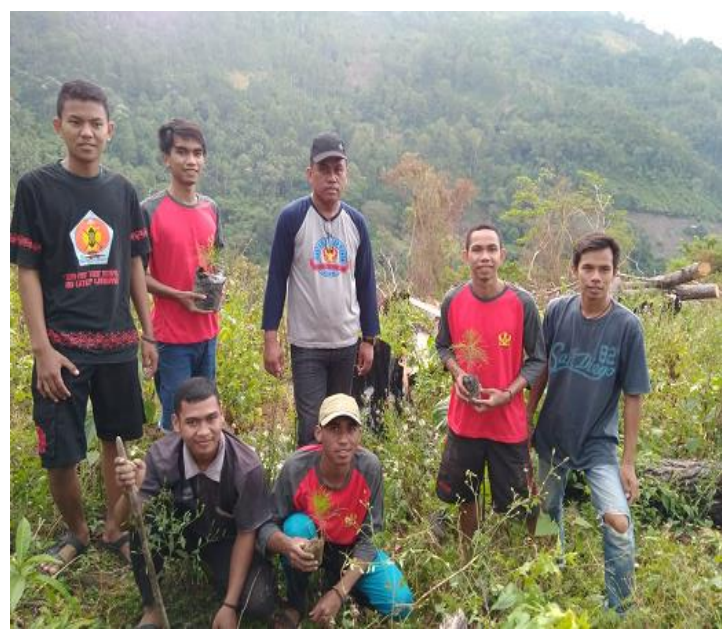

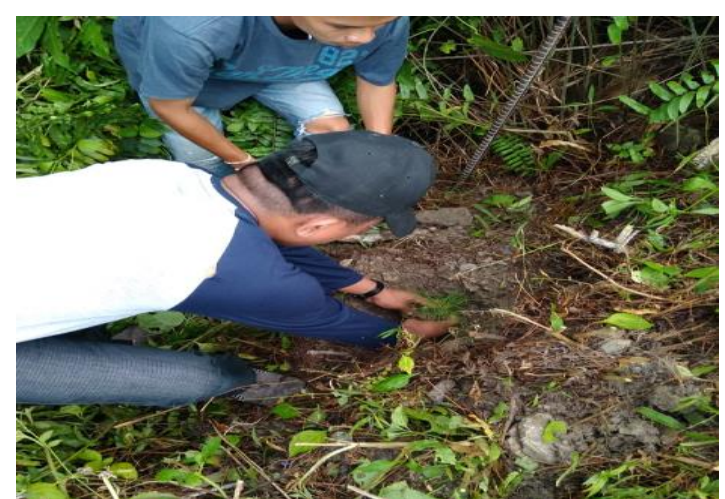

Gambar 11. Penanaman tanaman di lokasi ekowisata.

g. Pemasangan Sarana penunjang ekowisata Papan Nama Penunjuk Lokasi Ekowisata Desa.

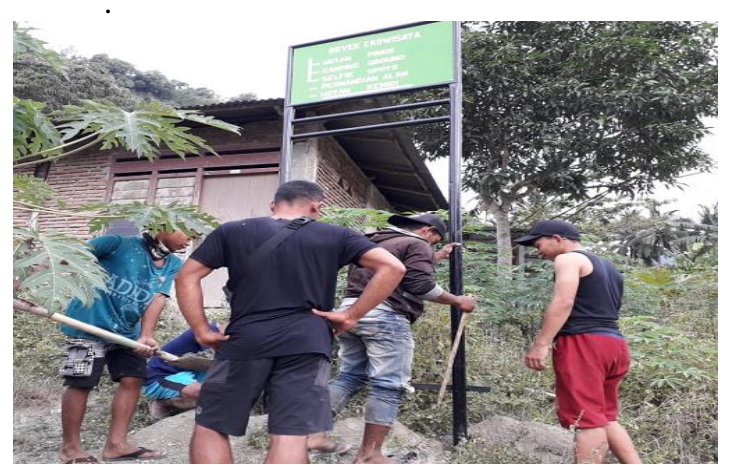

Gambar 12. Pemasangan Sarana penunjang ekowisata.

h. Pemeliharaan Bibit tanaman MPTS dan pendistribusian bibit ke anggota kelompok tani.
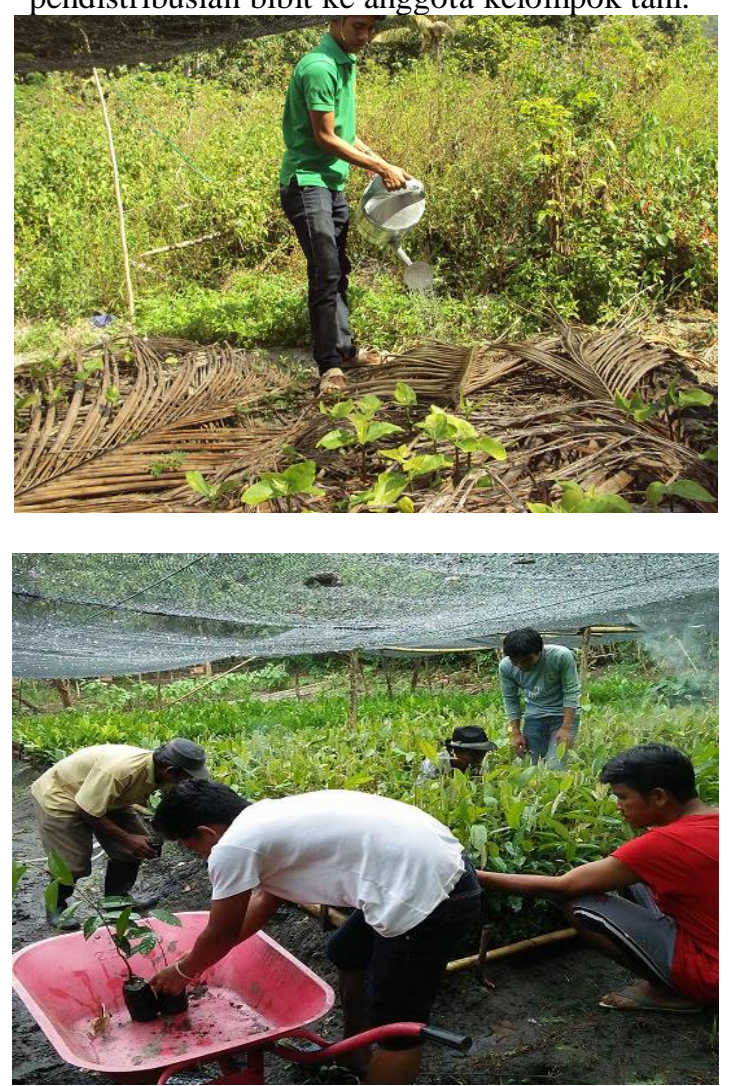

Gambar 13. Pemeliharaan dan pembagian bibit tanaman kepada anggota kelompok tani. 
i. Pelatihan bahasa Inggris dan penggunaan Global Positioning System (GPS) untuk penataan tata batas desa dan wilayah hutan Lindung.
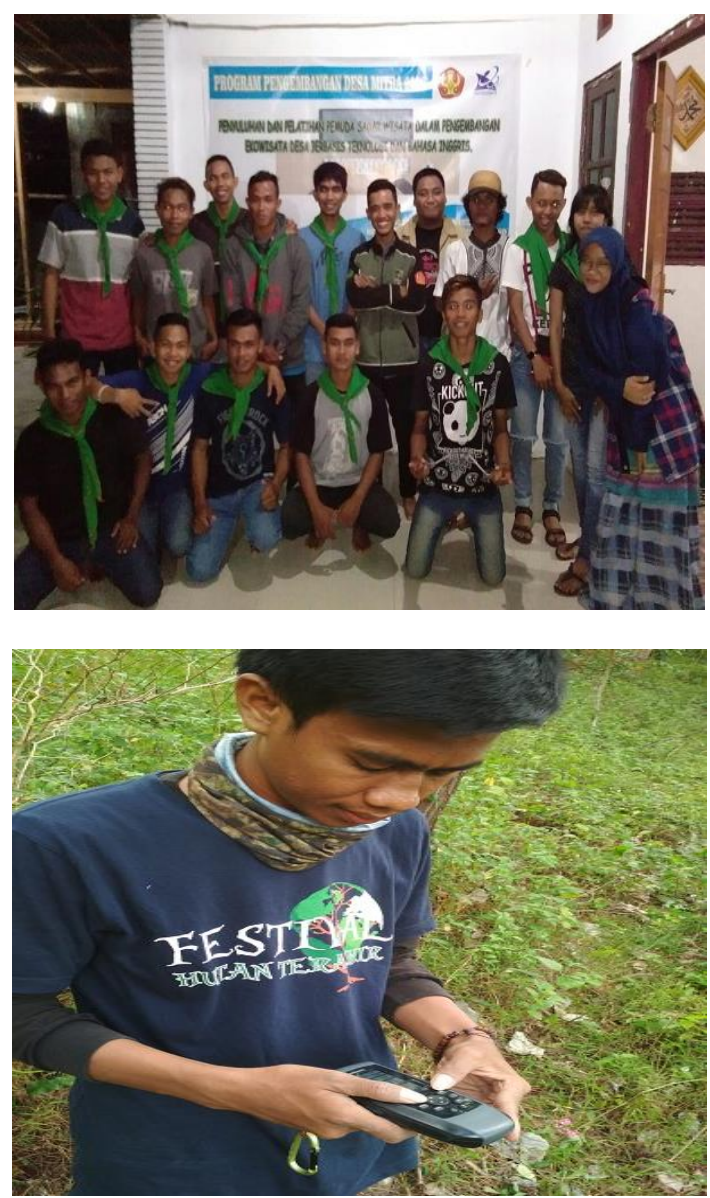

Gambar 15. Pelatihan Bahasa Inggris dan Penggunaan GPS bagi pemuda.

Kegiatan-kegiatan yang telah dilaksanakan memberikan dampak yang nyata bagi masyarakat sasaran antara lain:

1. Peningkatan pengetahuan masyarakat sasaran terutama dalam hal teknik budidaya tanaman MPTS yang termasuk pula persemaiannya, teknik pembuatan souvenir berbahan baku limbah tanaman pinus, Pembuatan terassering, Pembuatan souvenir berbahan baku limbah pinus, Pembuatan kuliner berbahan baku lokal, Strategi pengembangan potensi jasa lingkungan ekowisata desa, Dampak kebakaran hutan dan cara penanggulangannya, cara pembuatan Blog Desa Ekowisata dan Bahasa Inggris dan penggunaan GPS.

2. Peningkatan keterampilan masyarakat sasaran dalam hal pembuatan persemaian tanaman MPTS lainnya mulai dari pemilihan benih berkualitas, persiapan media tumbuh sampai pada pemeliharaaan bibit tanaman, pembuatan teraserring pada lahan miring, pembuatan souvenir dari limbah tanaman pinus dan diversifikasinya, pembuatan kuliner berbahan baku lokal setempat (umbi-umbian dan daun kelor), pembuatan blog desa ekowisata desa dan pelatihan bahasa Inggris dan penggunaan GPS bagi pemuda sadar wisata.
3. Peningkatan pendapatan masyarakat sasaran melalui penjualan produk-produk hasil dari pelatihan antara lain :

- Bibit tanaman sejumlah \pm 3000 bibit.

- Souvenir berbahan baku limbah pinus yang berupa gantungan kunci sebanyak \pm 1000 buah dan boneka burung sebanyak 500 buah.

- Snack Tortila dan Stick Daun Kelor yang sudah mulai diproduksi dan dijual di kios-kios di desa setempat.

- Kunjungan wisatawan lokal yang meningkat setiap minggu, baik yang mengunjungi areal camping ground, kolam pemandian alami maupun lokasi untuk foto (selfie spot).

4. Sebagian masyarakat yan terlibat dalam kegiatan pengabdian ini telah mempraktekkan pembuatan sengkedan/terassering di lokasi pertanaman sehingga aman dari erosi dan longsor.

5. Potensi ekowisata di desa ini lebih dikenal melalui promosi-promosi dalam bentuk leaflet maupun blog desa.

\section{KESIMPULAN}

Hasil nyata dari kegiatan-kegiatan yang telah dilakukan dalam program PPDM ini antara lain:

1. Peningkatan pengetahuan dan keterampilan masyarakat sasaran dalam hal teknik budidaya tanaman MPTS yang termasuk pula persemaiannya, teknik pembuatan souvenir berbahan baku limbah tanaman pinus, Pembuatan terassering, Pembuatan souvenir berbahan baku limbah pinus, Pembuatan kuliner berbahan baku lokal, Strategi pengembangan potensi jasa lingkungan ekowisata desa, dampak kebakaran hutan dan cara penanggulangannya, cara pembuatan Blog Desa Ekowisata dan Bahasa Inggris dan penggunaan GPS.

2. Peningkatan pendapatan masyarakat sasaran melalui penjualan-penjualan:

a. \pm 3000 bibit tanaman MPTS yang berkualitas yaitu Kemiri, Nangka, Bambu, Pala, dan Lada.

b. \pm 1500 Souvenir-souvenir berbahan baku limbah tanaman pinus dan diversifikasinya.

c. Kuliner yang berbahan baku lokal umbi-umbian seperti Tortila dan Stick Kelor.

d. Kunjungan wisatawan lokal ke obyek-obyek ekowisata yang ada.

3. Terdapat sarana-sarana penunjang ekowisata desa seperti papan penunjuk jalan permanen ke lokasi obyek ekowisata dan Blog Desa Ekowista Uwemanje sebagai sebagai ajang promosi.

4. Terdapat model pertanaman yang mengikuti kaidah konservasi, karena terdapat terassering/sengkedan.

\section{UCAPAN TERIMA KASIH}

Penulis menyampaikan ucapan terima kasih kepada Direktorat Riset dan Pengabdian Kepada Masyarakat, Direktorat Jenderal Penguatan Riset dan Pengembangan, Kementerian Riset, Teknologi dan Pendidikan Tinggi, atas dana hibah Sesuai Dengan Perjanjian Penugasan Pelaksanaan Program Pengabdian Masyarakat No.21/SP2H/PPM/DRPM/2018, Tanggal 9 
Maret 2018. Dan terima kasih pula kepada pemerintah dan seluruh masyarakat desa Uwemanje atas dukungan sarana dan prasarana selama program pengabdian dilaksanakan, juga kepada PEMDA Kabupaten Sigi melalui Dinas Lingkunag Hidup Sigi atas dukungan Narasumber dalam kegiatan penyuluhan.

\section{DAFTAR PUSTAKA}

Badan Pusat Statistik Kabupaten Sigi. (2015). Kabupaten Sigi Dalam Angka. Sigi: Badan Pusat Statistik Kabupaten Sigi.

Erfandi D. (2013). Teknik Konservasi Tanah Lahan Kering Untuk Mengatasi Degradasi Lahan Pada Desa Mojorejo Lamongan. Jurnal Bumi Lestari. 13(1), 91-97.

Krisnawati H, Kallio M,, dan Kanninen M. (2011). Aleurites moluccana Willd. Ekologi, Silvikultur dan Produktivitas. Bogor: Centre for International Foretsry Research (CIFOR).

Rasyid A., Ismani., dan N Setiawan. (2010). Strategi Pemberdayaan Masyarakat Berbasis Optimalisasi Pengelolaan Hasil Usaha Tani Sebagai Usaha Penanggulangan Kemiskinan Penduduk Desa di Wilayah Kabupaten Gunung Kidul, DIY. Jurnal Pendidikan Akuntansi Indonesia. 8, 58-72.

Rukmana, R. (1995). Teknik Pengelolaan Lahan Kritis dan Berbukit. Yogyakarta: Kanisius.

Shinta A. (2011). Ilmu Usaha Tani (h. 134). Malang: Universitas Brawijaya Press.

Subagyono K., S Marwanto., dan U Kurnia. (2003). Teknik Konservasi Tanah Secara Vegetatif. Balai Penelitian Tanah, Pusat Penelitian dan Pengembangan Tanah dan Agroklimat. Badan Penelitian dan Pengembangan Pertanian. Departemen Pertanian.

Suriadikusumah A. (2012). Ekowisata dan Agrowisata (Eko-Agrowisata) Alternatif Solusi Untuk Pengembangan Wilayah Pada Lahan-lahan Berlereng di Jawa Barat. Fakultas Pertanian, Universitas Padjajaran, Bandung.

Sutiyono. (2012). Budidaya Bambu. Pusat Penelitian dan Pengembangan Peningkatan Produktivitas Hutan. Bogor.

Suwastika A.A.N.G., N.W.S. Sutari., A.A.A.A.S. Sunari., N.N. Soniari., dan I.W.D. Atmaja. (2013). Pengolahan Limbah Pertanian dan Kerajinan Menjadi Pupuk Organik Berkualitas di Desa Taro, Kecamatan Tegallalang, Kabupaten Gianyar. Udayana Mengabdi. 12,16-19.

Widagdyo K.K. (2017). Pemasaran, Daya tarik ekowisata dan minat berkunjung wisatawan. Jurnal Bisnis dan Manajemen. 79(2), 261-276.

Yuniarti K. (2006). Teknologi Budidaya dan Pengolahan Bambu dan Rotan. Prosiding Ekspose/Diskusi Hasil-hasil Penelitian Balai Litbang Kehutanan Bali-Nusa Tenggara, Kupang. 